\title{
The use of Metronidazole in Clostridium Difficile Infection at Patients with Colorectal Cancers operated in Emergency
}

\author{
GEORGIANA BIANCA CONSTANTIN ${ }^{1}$, SORIN BERBECE ${ }^{2 *}$, DRAGOS VOICU ${ }^{2,3}$, \\ LUIZA NECHITA ${ }^{2,3}$, CORINA PALIVAN MANOLE ${ }^{2,3}$, ALEXANDRA TOMA ${ }^{2}$, \\ RAUL MIHAILOV ${ }^{2,3}$, OANA MIHAILOV ${ }^{2}$, BOGDAN STEFANESCU ${ }^{2,3}$, CIPRIAN DINU ${ }^{2}$ \\ 1 "Carol Davila" University of Medicine and Pharmacy, Faculty of Medicine, 8 Eroii Sanitari, 050474, Bucharest, Romania \\ 2 "Dunarea de Jos" University, Faculty of Medicine and Pharmacy, 35 Al. I. Cuza Str., 800216, Galati, Romania \\ 3 "Sf. Ap. Andrei" Clinical Emergency County Hospital, 177 Brailei Str., 800578, Galati, Romania
}

\begin{abstract}
Clostridium difficile infection has increased over the past decades. Surgical patients, especially those undergoing intestinal surgery, have higher rates of this infection. Patients infected with Clostridium difficile are more likely to have postoperative complications and higher rates of mortality. We will present the results of a retrospective study made in the $2^{\text {nd }}$ clinic of Surgery at the Clinical Emergency County Hospital "Sf. Ap. Andrei" Galati. This study includes 431 patients with complicated colorectal cancers operated in emergency between 2007 and 2016. All the patients infected with Clostridium difficile received oral Metronidazole. Only one of the infected patients presented a recurrence which was treated with oral vancomycin. The treatment of Clostridium difficile infection has become a global public health challenge. Colorectal surgery is a documented risk factor for Clostridium difficile infection. The prevalence of Clostridium difficile infection has grown in the last years and this increase has been particularly apparent among surgical patients. In a large intestine weakened by cancer, the risk of this infection can increase even more. New strategies to prevent the Clostridium difficile infection are required.
\end{abstract}

Keywords: colorectal cancer, complications, Clostridium difficile infection, impact, treatment

\section{Introduction}

Clostridium difficile is an anaerobic gram positive bacillus. It accounts 20-30\% of cases of antibiotic associated diarrhea [1] and it represents the leading cause of diarrhea in health care settings.

Clostridium difficile infection has increased over the past decades, augmenting in the same time the morbidity and mortality of other diseases. Surgical patients, especially those undergoing intestinal surgery, have higher rates of this infection. There have been identified some risk factors such as: older age, use of broad spectrum antibiotics, immunosuppression, prolonged time of preoperative hospital stay [2].

The usual presentation of Clostridium difficile infection includes the following findings: 1 . The presence of diarrhea defined as passage of 3 or more unformed stools in 24 or fewer consecutive hours 2. A stool test positive for the presence of toxigenic Clostridium difficile or its toxins or colonoscopic or histopathologic findings demonstating pseudomembranous colitis [2, 3].

The clinical spectrum ranges from mild to severe or life threatening (ileus, toxic megacolon).

For non-severe Clostridium difficile infection, oral metronidazole or oral vancomycin is the treatment_of choice [4]. First recurrence is encountered with oral vancomycin [3].

There are no evidences for anion-exchange resins (cholestyramine), probiotics, immunoglobulins and monoclonal antibodies to Clostridium difficile toxins, to decrease the number of recurrences [5].

The incidence of Clostridium difficile infection in patients undergoing gastrointestinal surgery ranges from 0.28 to $6.8 \%$ [6-10]. The highest percentage is referred to colorectal cancer surgery. 
It is well known that normal bacterial flora in the intestine has been shown to be destroyed by antibiotics, thus Clostridium difficile spores colonize the intestine and cause the infection. Prior antibiotic treatment [9], and even short courses of prophylactic antibiotics may be associated with Clostridium difficile infection [11,12].

Colorectal surgery has been reported as a risk factor for Clostridium difficile infection in many studies. It has been suggested that functional intestinal obstruction predisposes in Clostridium infection by altering the normal bacterial flora of the intestine and thus facilitates the colonization [13].

The surgical patients infected with Clostridium difficile have a much higher mortality rate compared with patients without this infection [14-16].

Moreover, patients infected with Clostridium difficile are more likely to have postoperative complications and to be readmitted within 30 days of initial discharge [14].

\section{Materials and methods}

We will present the results of a retrospective study made in the $2^{\text {nd }}$ clinic of Surgery at the Clinical Emergency County Hospital "Sf. Ap. Andrei" Galati. This study includes 431 patients with complicated colorectal cancers operated in emergency between 2007 and 2016.

We examined the patient-related risk factors for Clostridium difficile infection, the treatment received (especially the antibiotics and their effects), the time spent in hospital and the complications occurred.

\section{Results and discussions}

$42(9,74 \%)$ of the patients included in this study developed postoperatory complications (Figure 1). The Clostridium difficile infection interfered with the evolution of $16,6 \%$ of the patients with postoperatory complications.

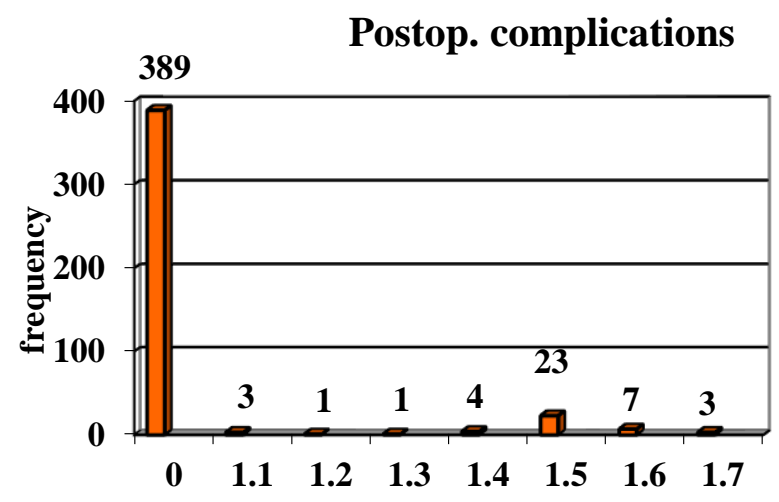

$$
\begin{aligned}
& \text { 0-no } \\
& \text { 1.1- intestinal obstruction } \\
& \quad \text { (adherential syndrome) } \\
& \text { 1.2-ischiorectal phlegmon } \\
& \text { 1.3-pancreatic fistula } \\
& \text { 1.4-intestinal fistula } \\
& \text { 1.5-parietal suppuration } \\
& \text { 1.6-Clostridium difficile } \\
& \text { 1.7-blocked evisceration }
\end{aligned}
$$

Figure 1. Postoperatory complications

None of these patients received antibiotic treatment before the surgery, but all of them received antibiotics in the postoperatory period.

4 of these patients had sigmoid tumors, 2 rectal tumors and 1 patient had an anastomotic colo-colic tumor.

The lab results have shown both toxin A and toxin B positive in all infected patients. It is considered that toxins A and B act as glucosyltransferases, promoting the activation of Rho GTPases leading to disorganization of the cytoskeleton of the colonocyte, and eventual cell death.

The treatment received was oral Metronidazole. Only one of the infected patients presented a recurrence which was treated with oral vancomycin (Table 1). 
Table 1. Patients' data

\begin{tabular}{|c|c|c|c|c|c|c|}
\hline $\begin{array}{l}\text { Tumor's } \\
\text { location }\end{array}$ & Age & $\begin{array}{l}\text { Number of } \\
\text { days spent in } \\
\text { hospital }\end{array}$ & $\begin{array}{l}\text { Antibiotic treatment } \\
\text { used postop. }\end{array}$ & $\begin{array}{l}\text { Clostridium } \\
\text { difficile } \\
\text { treatment }\end{array}$ & Recurrences & Mortality \\
\hline Sigmoid $n=4$ & $47 \ldots 79$ & $8 \ldots 19$ & \multirow[t]{3}{*}{$\begin{array}{l}\text { Cephalosporines +/- } \\
\text { Metronidazole i.v. }\end{array}$} & $\begin{array}{l}\text { Metronidazole } \\
\text { per os }\end{array}$ & $\mathrm{n}=0$ & $\mathrm{n}=0$ \\
\hline Rectum $n=2$ & 59,77 & $7 \ldots 13$ & & $\begin{array}{l}\text { Metronidazole } \\
\text { per os }\end{array}$ & $\mathrm{n}=0$ & $\mathrm{n}=0$ \\
\hline $\begin{array}{c}\text { Anastomotic } \\
\mathrm{n}=1\end{array}$ & 56 & 17 & & $\begin{array}{c}\text { Metronidazole } \\
\text { per os followed } \\
\text { by } \\
\text { Vancomycine } \\
\text { per os }\end{array}$ & $\mathrm{n}=1$ & $\mathrm{n}=1$ \\
\hline
\end{tabular}

All of the patients received oral Metronidazole for the Clostridium difficile infection treatment. In this study, we found only one recurrence (at a patient with an anastomotic colo-colic tumor), that was treated with oral Metronidazole and Vancomycine. Unfortunately, the evolution of this patient was not favourable.

The statistical survival analysis revealed no significant difference between the patients who developed Clostridium difficile pseudomembranous colitis and those who did not $(p=0,372)$ (Figure 2).

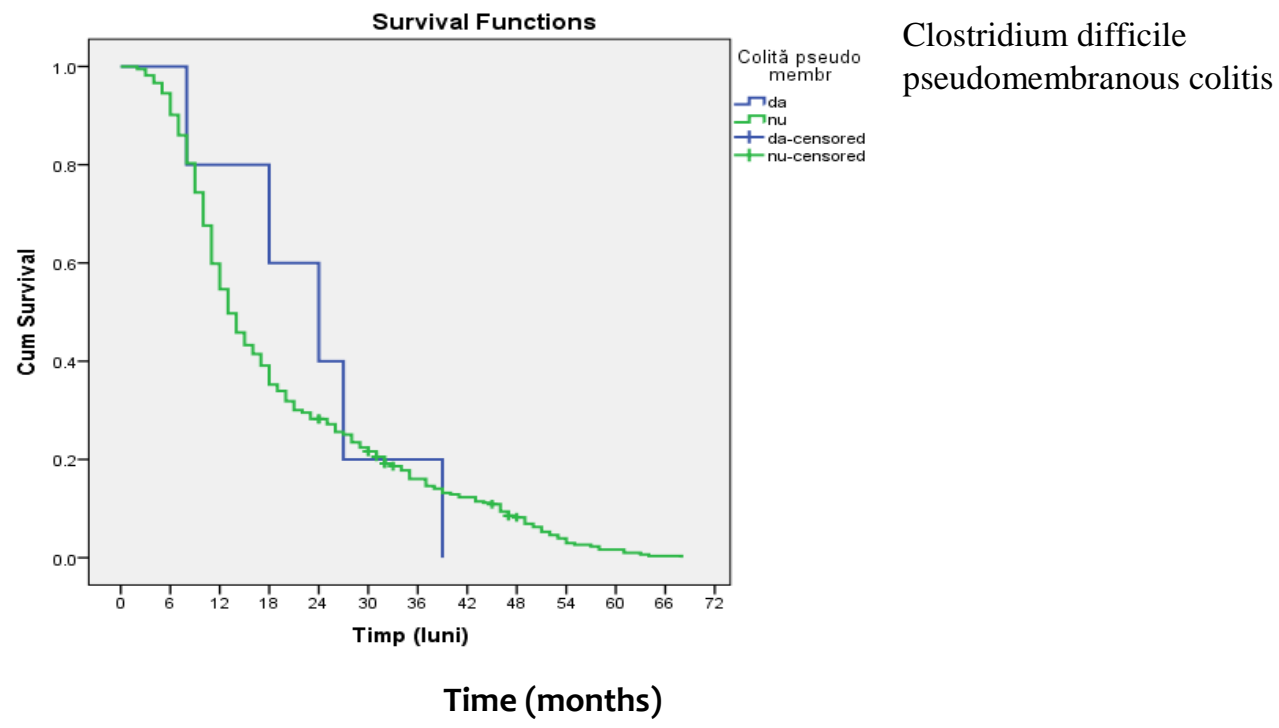

Figure 2. Survival analysis

Pharmacokinetic differences between the two drugs may play a role in treatment failure [17]. In patients receiving oral metronidazole, concentrations of metronidazole are higher in watery stools at the start of treatment, but decrease as diarrhea improves and colonic inflammation subsides [17]. In contrast, stool concentrations of orally administered vancomycin remain high throughout therapy [18]. Studies also suggest that the rates of colonization and persistent overgrowth of vancomycin-resistant enterococci may be equivalent in patients who are treated with oral vancomycin or with oral metronidazole [19-21]. Clinical practice is shifting toward using oral vancomycin, and several best practice documents recommend using oral vancomycin as initial therapy for severe Clostridium difficile infection [22-24].

The treatment of Clostridium difficile infection has become a global public health challenge.

New clinical practice guidelines for managing Clostridium difficile infection were recently published by the Infectious Disease Society of America (IDSA) [22]. No recommendations were specific to patients with complicated colorectal cancers. Additional studies on Clostridium dificile 
infection disease progression and incidence rates, as well as on changes to the gut environment associated with solid colic tumors will be necessary.

In 2015, a systematic review and meta-analysis comparing the efficacy and safety of metronidazole monotherapy with vancomycin monotherapy and combination therapy in Clostridium difficile infection patients was published [23]. No statistically significant difference [24] in the rate of clinical cure was found between metronidazole and vancomycin for mild Clostridium difficile infection $(p=0,05)$ or between either monotherapy and combination therapy for Clostridium difficile infection $(\mathrm{p}=0,83)$; however, the rate of clinical cure was lower for metronidazole than for vancomycin for severe Clostridium difficile infection.

In 2017, in an update of a previously published Cochrane review, moderate quality evidence suggested that vancomycin is superior to metronidazole in all cases of Clostridium difficile infection [25]. The differences in effectiveness between these antibiotics were not too large and the advantage of metronidazole is its far lower cost.

Colorectal surgery is a documented risk factor for Clostridium difficile infection [26, 27]. Damle et al. [14] published a retrospective analysis of patients who developed the infection following colorectal resection. The authors identified adult patients undergoing colorectal surgery between 2008 and 2012 from the US University Health System Consortium database. A total of 84,648 patients met study inclusion criteria. Clostridium difficile infection occurred in 1266 (1.5\%) patients. The strongest predictors were emergency procedure, inflammatory bowel disease, and severity of illness score.

In addition to the large spectrum antibiotic treatment $[28,29,30]$ (such as cephalosporines, in our case), using proton pump inhibitors has also been reported as a risk factor [31]. Proton pump inhibitors have been used in all the patients in this study. In 2012, a systematic review of incident and recurrent Clostridium difficile infection in proton pump inhibitors users was published [32]. Forty-two observational studies (30 case-control, 12 cohort) totaling 313,000 participants were evaluated. Despite the substantial statistical and clinical heterogenety, the findings indicated a probable association between proton pump inhibitors use and incident and recurrent Clostridium difficile infection. This risk was further increased by concomitant use of antibiotics and proton pump inhibitors.

Our study does not include a very large number of patients, but the results found are according to the medical literature data, from the oldest to the new ones [33, 34]. However, new studies and metaanalysis on the subject are required.

\section{Conclusions}

The prevalence of Clostridium difficile infection has grown in the last years and this increase has been particularly apparent among surgical patients. The mortality and costs associated with postsurgical Clostridium difficile infection indicate the necessity of prompt identification of high risk patients so that rapid diagnosis and treatment can be applied. Measures such as reduction of preoperative hospital stay, restrictions of broad spectrum antibiotics and strict policy of surgical chemoprophylaxis, may contribute to further reduction of this infectious disease. The increased costs also highlight the importance of prevention strategies targeting high-risk patients.

This study demonstrates the efficacy of metronidazole treatment, keeping vancomycin as an option for complicated and recurrent cases of Clostridium difficile infections. Moreover, international studies do not reveal any essential differences between metronidazole or vancomycin treatment. The similar efficacy of the two drugs is also proven by the unfavorable evolution of the only complicated case treated with vancomycin after the initial similar treatment with metronidazole.

Despite the complications generated in the postoperative evolution of patients and the challenges related to the therapeutic option, Clostridium difficile infection does not aggravate the prognosis of the patients and does not significantly change the survival statistics.

In a large intestine weakened by cancer, the risk of this infection can increase even more.

Clostridium difficile-associated colitis may prolong the hospital stay after surgery and increase cost. Therefore, new strategies to prevent the Clostridium difficile infection are required. 


\section{References}

1.BARLETT, J.G. Antibiotic associated colitis. Clin Microbiol Infect., 30, 1984, p. 1-54.

2.MASGALA, A., DELIS, S.G., DERVENIS, C. Clostridium Difficile Infection: An Increasing Postsurgical Complication. J Infect Dis Ther., 2, 2014, p. 176. doi: 10.4172/2332-0877.1000176

3STUART, H.C., DALE, N.G., STUART, J., CIARAN, P.K., VIVIAN, G.L., et al. Clinical Practice Guidelines for Clostridium Difficile Infection in Adults: 2010 Update by the Society for Healthcare Epidemiology of America (SHEA) and the Infectious Diseases Society of America (IDSA) Infection Control and Hospital Epidemiology., 31, 2010, p. 434-456.

4.DEBAST, S.B., BAUER, M.P., KUIJPER, E.J. European Society of Clinical Microbiology and Infectious Diseases: update of the treatment guidance document for Clostridium Difficile infection. Clin Microbiol Infect., 20, Suppl 2, 2014, p. 1-26.

5.OlEASTRO, M., COELHO, M., GIAO, M., COUTINHO, S., MOTA, S., et al. Outbreak of Clostridium Difficile PCR ribotype 027-the recent experience of a regional hospital. BMC Infect Dis., 14, 2014, p. 209.

6.KRAPOHL, G.L., MORRIS, A.M., CAI, S., ENGLESBE, M.J., ARONOFF, D.M., et al. Preoperative risk factors for postoperative Clostridium Difficile infection in colectomy patients. Am J Surg., 205, 2013, p. 343-347.

7.KENT, K.C., RUBIN, M.S., WROBLEWSKI, L., HANFF, P.A., SILEN, W. The impact of Clostridium Difficile on a surgical service: a prospective study of 374 patients. Ann Surg, 227, 1998, p. 296-301.

8.YASUNAGA, H., HORIGUCHI, H., HASHIMOTO, H., MATSUDA. S., FUSHIMI, K. The burden of Clostridium difficile-associated disease following digestive tract surgery in Japan. J Hosp Infect., 82, 2012, p. 175-180.

9.LUNDEEN, S.J., OTTERSON, M.F., BINION, D.G., CARMAN, E.T., PEPPARD, W.J. Clostridium Difficile enteritis: an early postoperative complication in inflammatory bowel disease patients after colectomy. J Gastrointest Surg., 11, 2007, p. 138-142.

10.NISTOR, C., FUDULU, D. P., PANTILE, D., Horvat, T. BMJ case reports, 2016, bcr2016217431. https://doi.org/10.1136/bcr-2016-217431

11.CRABTREE, T.D., PELLETIER, S.J., GLEASON, T.G., PRUETT, T.L., SAWYER, R.G. Clinical characteristics and antibiotic utilization in surgical patients with Clostridium difficile-associated diarrhea. Am Surg., 65, 1999, p. 507-511.

12.SHAH, K., PASS, L.A., COX, M., LANHAM, M., ARNOLD, F.W. Evaluating contemporary antibiotics as a risk factor for Clostridium Difficile infection in surgical trauma patients. J Trauma Acute Care Surg., 72, 2012, p. 691-695.

13.YEOM, C.H., CHO, M.M., BAEK, S.K., BAE, O.S. Risk Factors for the Development of Clostridium difficile-associated Colitis after Colorectal Cancer Surgery. J Korean Soc Coloproctol., 26, 2010, p. 329-333.

14.DAMLE, R.N., CHERNG, N.B., FLAHIVE, J.M., DAVIDS, J.S., MAYKEL, J.A., et al. Clostridium Difficile Infection After Colorectal Surgery: A Rare but Costly Complication. $J$ Gastrointest Surg., 18, 2014, p. 1804-1811.

15.ZEREY, M., PATON, B.L., LINCOURT, A.E., GERSIN, K.S., KERCHER, K.W., et al. (2007) The burden of Clostridium Difficile in surgical patients in the United States. Surg Infect (Larchmt), 8, p. 557-566.

16.NISTOR, C., RANETTI, A.E., CIUCHE, A., PANTILE, D., CONSTANTIN, L., BRANCOVEANU, R. (2014) Farmacia, 62 (5), pp. 897-906

17.DUPONT, H.L., GAREY, K., CAEIRO, J.P., JIANG, Z.D. New advances in Clostridium difficile infection: changing epidemiology, diagnosis, treatment and control. Curr Opin Infect Dis., 21, nr. 5, 2008, p. 500-507.

18.HALSEY J. Current and future treatment modalities for Clostridium difficile-associated disease. Am J Health Syst Pharm., 65, nr. 8, 2008, p.705-715. 
19.AL-NASSIR, W.N., SETHI, A.K., LI, Y., PULTZ, M.J., RIGGS, M.M., DONSKEY, C.J. Both oral metronidazole and oral vancomycin promote persistent overgrowth of vancomycin-resistant enterococci during treatment of Clostridium difficile-associated disease. Antimicrob Agents Chemother., 52, nr. 7, 2008, p. 2403-2406.

20.MILLER, M.F., BERNARD, L., THOMPSON, M., GRIMA, D., PEPIN, J. Lack of increased colonization with vancomycinresistant enterococci during preferential use of vancomycin for treatment during an outbreak of healthcareassociated Clostridium difficile infection. Infect Control Hosp Epidemiol., 31, nr. 7, 2010, p.710-715.

21.***www.publichealthontario.ca. Available online: https://www.publichealthontario.ca/-/media/ documents/ cdiff-testing-surveillance-management.pdf?la=en

22.McDONALD, L.C., GERDING, D.N., JOHNSON, S., BAKKEN, J.S., KAREN, C., et al. Clostridium difficile Infection in Adults and Children: 2017 Update by the Infectious Diseases Society of America (IDSA) and Society for Healthcare Epidemiology of America (SHEA). Clinical Infectious Diseases, 66, nr. 7, 2018, p. e1-e48.

23.LI, R., LU, L., LIN, Y., WANG, M., LIU, X. Efficacy and safety of metronidazole monotherapy versus vancomycin monotherapy or combination therapy in patients with Clostridium difficile infection: a systematic review and meta-analysis. PLoS One., 10, 2015, p. e0137252.

24.NISTOR, C.E., STADEN, R.S., DUMITRU, A.V., STANCIU GAVAN, C. J Clin Med. 2019 Dec 27;9(1). pii: E76. doi: 10.3390/jcm9010076. PubMed PMID: 31892209.

25.NELSON, R.L., SUDA, K.J., EVANS, C.T. Antibiotic treatment for Clostridium difficileassociated diarrhoea in adults. Cochrane Database Syst Rev., 3, 2017, p. CD004610.

26.WREN SM, AHMED N, JAMAL A, SAFADI BY. Preoperative oral antibiotics in colorectal surgery increase the rate of Clostridium difficile colitis. Arch Surg., 140, 2005, p. 752-6.

27.YEOM, C.H., CHO, M.M., BAEK, S.K., BAE, O.S. Risk factors for the development of Clostridium difficile-associated colitis after colorectal Cancer surgery. J Korean Soc Coloproctol., 26, 2010, p. 329-33.

28.NISTOR, C., CIUCHE, A., CONSTANTINESCU, I. Acta endocrinologica (Bucharest, Romania : 2005), 13(3), 370-374. https://doi.org/10.4183/aeb.2017.370

29.GRIGORE, N., TOTAN, M., PIRVUT, V., MITARIU, S.I.C., CHICEA, R., SAVA, M., HASEGAN, A., A Risk Assessment of Clostridium Difficile Infection after Antibiotherapy for Urinary Tract Infections in the Urology Department for Hospitalized Patients, Rev. Chim., 68(7), 2017, 1453 1456.

30.NISTOR, C., CIUCHE, A., PANTILE, D., DAVIDESCU, M., RANETTI, A. (2013) Farmacia. 61. 764-771.

31.KAZAKOVA, S.V., WARE, K., BAUGHMAN, B., BILUKHA, O., PARADIS, A., SEARS, S., et al. A hospital outbreak of diarrhea due to an emerging epidemic strain of Clostridium difficile. Arch Intern Med., 166, 2006, p. 2518-2524.

32.KWOK, C.S., ARTHUR, A.K., ANIBUEZE, C.I., SINGH, S., CAVALLAZZI, R., LOKE Y.K. Risk of Clostridium difficile infection with acid suppressing drugs and antibiotics: meta-analysis. Am J Gastroenterol.,107, 2012, p. 1011-1019.

33.LUPU, M., SANDU, M.N., TURCANU, R., ARITON, C., Effectiveness of Prevention of Clostridium difficile Infection by Chemical Methods, Rev. Chim., 71(1), 2020, 360-363

34.MARINESCU, A.R., LAZUREANU, V., LAZA, R., MUSTA, V., NICOLESCU, N., LICKER, M., Clostridium difficile Infection in Western Romania: Correlations Between Ribotype and Clinical Form One year observational retrospective study, Rev. Chim., 70(7), 2019, 2660-2664.

$\overline{\text { Manuscript received: } 25.09 .2019}$ 